\title{
Evaluation of the changes induced by gasification biochar in a peat-sand substrate**
}

\author{
Olga Muter ${ }^{*}$, Galina Lebedeva ${ }^{2}$, and Galina Telysheva ${ }^{2}$ \\ ${ }^{1}$ Institute of Microbiology and Biotechnology, University of Latvia, 4 Kronvalda Blvd., Riga, LV-1010, Latvia \\ ${ }^{2}$ Latvian State Institute of Wood Chemistry, 27 Dzerbenes St., LV-1006 Riga, Latvia \\ Received October 25, 2013; accepted September 3, 2014
}

\begin{abstract}
A b s t r a c t. Gasification biochar represents one of the biochar types tested for agricultural needs. The aim of this study was to clarify the physico-chemical and biological changes occurring in a peat-sand substrate amended with hardwood-derived gasification biochar in the rates of 2, 4 and $20 \mathrm{~g} \mathrm{l}^{-1}$. The $\mathrm{pH}\left(\mathrm{H}_{2} \mathrm{O}\right)$ of the substrate with $4 \mathrm{~g} \mathrm{l}^{-1}$ and $20 \mathrm{~g} \mathrm{l}^{-1}$ biochar was increased from 5.6 to 6.2 and 6.7 , respectively. The testing of the substrate in the respirometry device showed that the increase in the biochar rate led to a decrease in the amount of $\mathrm{CO}_{2}$ evolved at the maximum pressure drop. The continuous decrease in pressure observed in the respirometry bottles filled with pure biochar allows explaining this effect by biochar sorption activity. Addition of 2 and $4 \mathrm{~g} \mathrm{l}^{-1}$ biochar to the peat-sand substrate stimulated the growth of cucumbers in an 18-day pot vegetation experiment. An increase in the number of root tips and root volume with a decreasing average root diameter was shown in the presence of biochar. Stimulation of plant growth on the background of low rates of biochar requires a further study with emphasis on the specific combination of biochar, soil type, plant species, and climatic conditions.

$\mathrm{K}$ e y w o r d s: gasification biochar, plant growth, $\mathrm{CO}_{2}$ evolution, soil, buffering capacity
\end{abstract}

\section{INTRODUCTION}

The use of different types of biochar (BC) in agriculture for soil quality improvement attracts great attention of both, researchers and farmers. In spite of a huge number of reports regarding the effects of $\mathrm{BC}$ on soil physico-chemical properties, plant growth and microbial activity, the impact of $\mathrm{BC}$ under different conditions is still not understood. Life cycle assessments and economic calculations

*Corresponding author e-mail: olga.muter@inbox.lv

**This work was supported by the National Research Programme of Latvia No. 2010.10-4/VPP-5 'Sustainable Use of Local Resources(Mineral Deposits, Forests, Food and Transport)-New Products and Technologies', projects Y3-26493. The collegial support by 'Knavas granulas' Ltd. (leader E. Samulis) in providing biochar from their gasification devices is gratefully acknowledged. of $\mathrm{BC}$ application should be conducted on a site-specific basis (Stavi, 2013). Liu et al. (2013) summarized the recent publications on the topic and found that greater responses to $\mathrm{BC}$ addition were shown in pot experiments than in the field, in acid than in neutral soils, in sandy textured than in loam and silt soils.

Peat is one of the few materials available on the market, which possess entirely suitable aeration and water retention qualities, which is important for plant roots. Peat used for soil-less horticultural production systems can be amended with some products, especially to enhance the growing medium aeration and water holding capacity; besides, this contributes indirectly to reduction of the use of peat in horticulture (Johnson et al., 2012; Michel, 2010; Steiner and Harttung, 2014; Tian et al., 2012). As reported by many authors, the experiments with peat-containing substrates amended with $\mathrm{BC}$ have shown their potential in agriculture. In particular, moss peat amended with pellets containing equal proportions of $\mathrm{BC}$ and wood flour was shown to be a suitable substrate for cultivation of plants. Amixture of $75 \%$ peat and 25\% BC pellets had enhanced hydraulic conductivity and greater water availability (Dumroese et al., 2011).

Another important issue in the discussion on peat substitution by biochar is peat as a source of greenhouse gases once the peat land is drained, extracted, aerated, limed, and fertilized (Cleary et al., 2005, Steiner and Harttung, 2014). Components of biochar are more recalcitrant than soil organic matter, and, therefore, biochar provides carbon input into soil to be increased greatly compared to the carbon output through soil microbial respiration (Lehmann et al., 2006; Verheijen et al., 2009).

(C) 2014 Institute of Agrophysics, Polish Academy of Sciences 
The liming potential of $\mathrm{BC}$ plays a positive role as an amendment to the acidic peat substrate. Different physicochemical and biological changes in soil amended with $\mathrm{BC}$ are BC-specific and can depend on soil type, BC particle size, contact time etc. (Olszewski et al., 2013). Along with $\mathrm{pH}$ changes, the shift in soil physico-chemical properties is characterized by electrical conductivity (EC), cation exchange capacity (CEC), and exchangeable acidity (Chintala et al., 2013).

Biochars produced at higher temperature had a higher $\mathrm{pH}$, whereas those produced at lower temperatures had more sites for holding nutrients for plant growth (Novak et al., 2009). An increase in pyrolysis temperature and $\mathrm{BC}$ activation decreased the availability of $\mathrm{K}, \mathrm{P}$, and $\mathrm{S}$ compared to non-activated biochar produced at $350^{\circ} \mathrm{C}$. $\mathrm{BC}$ increased the content of dissolved organic carbon, total $\mathrm{N}$ and $\mathrm{P}, \mathrm{PO}_{4}^{3-}, \mathrm{SO}_{4}^{2-}$, and $\mathrm{K}$ at a rather high application rate $\left(40 \mathrm{~g} \mathrm{~kg}^{-1}\right)$ (Hass et al., 2012). In the leaching experiments, the presence of $\mathrm{BC}$ increased the $\mathrm{pH}$ of column leachate from 0.08 to 1.70 and significantly decreased the cumulative amount of mineral $\mathrm{N}$ leached from the soil (Angst et al., 2013). However, leaching of different elements is case-specific. For instance, $\mathrm{K}, \mathrm{P}$, and $\mathrm{Mg}$ have contrasting associations with hardwood biochar that govern the trajectory and ultimate extent of their release (Angst et al., 2013). Some BCs increased the soil water retention and $\mathrm{pH}$, while other biochars increased soil sodium and phosphorus content (Novak et al., 2009).

Biological processes occurring in biochar-amended soil are also affected by $\mathrm{pH}$ changes. For instance, Cayuela et al. (2013) suggested a function of biochar as an 'electron shuttle' that facilitates the transfer of electrons to soil denitrifying microorganisms, which together with its liming effect would promote the reduction of $\mathrm{N}_{2} \mathrm{O}$ to $\mathrm{N}_{2}$.

Our previous results demonstrated a stimulating effect of the hard wood-derived gasification biochar (BC-G)on pea Pisum sativum L. in loamy sand soil and cucumber Cucumis sativus L. in a peat-sand substrate at a comparatively low application rate (Telysheva et al., 2013).

The aim of this study was to clarify the physicochemical and biological changes occurring in a peat-sand substrate with addition of BC-G in the rate of 2, 4 and 20 $\mathrm{g} \mathrm{l}^{-1}$ biochar. It was expected that a comparative study of the samples with different biochar concentrations in the respirometry device could give new data related to the effect of BC-G on physicochemical characteristics in the integral system containing peat, sand, BC-G, microorganisms, soluble nutrients etc.

\section{MATERIALS AND METHODS}

Biochar (BC-G) was obtained from hardwood by gasification under conditions of the original pilot plant 'Knavas granulas', Vilanu district, Latvia, with the total electroenergy capacity of about $500 \mathrm{MW}$. The original technology is licensed. The gasification hybrid technology GreenEngine was developed and commercialized in Latvia (www.enter- tecgreen.com). Gasification of granulated biomass proceeds in a two-stage reactor with separate zones of fast pyrolysis (zone of low temperature) and a zone of actual gasification (zone of high temperature). Gas temperature in the gasification reactor can reach $1150^{\circ} \mathrm{C}$. The yield of the carbonized residue is up to 15 with $96 \%$ carbon content. The density of BC-G was $0.3 \mathrm{~g} \mathrm{~cm}^{-3}$, and particle size $0.10-0.25 \mathrm{~mm}$. The peat substrate (KKS-1, Laflora Ltd., Latvia) used had the following properties: particle size $0-5 \mathrm{~mm} ; \mathrm{pH}(\mathrm{KCl})$ $5.9 \pm 0.3$; $\mathrm{ES} \mathrm{mS} \mathrm{cm}^{-1} 1.8 \pm 0.3$.

Peat was mixed with sand in a ratio $3: 1$ by volume and then sieved through $\varnothing 2.5 \mathrm{~mm}$. The peat-sand substrate obtained had $40 \%$ moisture content and one litre of it had a weight $500 \mathrm{~g}$ (or $300 \mathrm{~g}$ of dry mass). The substrate was divided into 4 parts to prepare BC-G-amended samples ie $0,2,4$, and $20 \mathrm{~g} \mathrm{l}^{-1}$ biochar. Testing of the peat-sand mix was performed in triplicate.

Dry weight was determined by drying the soil samples at $105^{\circ} \mathrm{C}$ until constant weight. The $\mathrm{pH}$ value was measured in distilled water, $1 \mathrm{M} \mathrm{KCl}$, and $1 \mathrm{M} \mathrm{CH}_{3} \mathrm{COONa}(10 \mathrm{~g}$ soil in $50 \mathrm{ml}$ ) with a $\mathrm{pH}$-meter Hanna $\mathrm{pH} 213$.

The buffering capacity of the peat-sand substrate with 4 $\mathrm{gl}^{-1}$ biochar and without BC-G was assessed after the addition of increasing amounts of $0.1 \mathrm{~N} \mathrm{H}_{2} \mathrm{SO}_{4}$ or $0.1 \mathrm{~N} \mathrm{NaOH}$ to the $5 \mathrm{~g}$ substrate suspended in deionized water. The total volume of the suspensions was $13 \mathrm{ml}$. The $\mathrm{pH}$ value in the suspensions was measured after $24 \mathrm{~h}$ incubation at $22^{\circ} \mathrm{C}$ with periodical shaking.

Water holding capacity (WHC) of the peat-sand substrate was determined by immersing $50 \mathrm{~cm}^{3}$ air-dried samples in water for 3 days until they reached constant weight. The tube was then placed in a vertical position for two hours to allow excess water to drain. Afterwards, the samples were dried at $105^{\circ} \mathrm{C}$ until constant weight. The maximum WHC was calculated as the amount of water retained by the soil against gravity, based on the oven-dry weight at $105^{\circ} \mathrm{C}$.

The number of aerobic heterotrophic microorganisms and fungi was determined by cultivation on Tryptone Glucose Yeast Extract Agar and Sabouraud Chloramphenicol Agar (Sifin, Germany), respectively. Colony forming units (CFU) were counted after $96-\mathrm{h}$ plate incubation at $28^{\circ} \mathrm{C}$.

$\mathrm{CO}_{2}$ evolution was measured using the OxiTop® OC 110 respirometric system (WTW, Germany). The OxiTop system represents an elegant, easy handled and sufficient alternative to the other, more expensive respirometric equipment (Černohlávková et al., 2009). The principle of the operation is a pressure drop in the closed system due to absorption of the released $\mathrm{CO}_{2}$ in $\mathrm{NaOH} .20 \mathrm{~g}$ substrate (dw $73 \div 76 \%$ ) was placed in a bottle; afterwards $18 \mathrm{ml}$ distilled water containing $1 \mathrm{~g}$ glucose was added. Fresh $\mathrm{NaOH}$ granules were added for each incubation set. Manometric measurement of the changes in the vacuum was performed automatically every $12 \mathrm{~min}$. The incubation was performed at $20^{\circ} \mathrm{C}$ in dark without agitation. Data collected during the incubation were sent to the controller through infrared 
interface and then to the computer using AchatOC software. The correlation between changes in the number of moles of substance and pressure drop was calculated using the following equation (Sadaka et al., 2006):

$$
\Delta n=\frac{\Delta P V}{R T}
$$

where: $\Delta n$ is the changes in the number of moles of the substance $(\mathrm{kmol}), \Delta P$ is the pressure drop $(\mathrm{kPa}), V$ is the gas volume $\left(\mathrm{m}^{3}\right), R$ is the general gas constant $\left(8.134 \mathrm{~kJ} \mathrm{kmol}^{-1}\right.$, $\left.{ }^{\circ} \mathrm{K}^{-1}\right), T$ is the gas temperature $\left({ }^{\circ} \mathrm{K}\right)$.

The vegetation test was carried out in triplicate in 101 boxes $(37 \times 28 \times 10 \mathrm{~cm})$ in a warmed glasshouse. Boxes were filled with a peat-sand substrate amended with 2 and $4 \mathrm{~g} \mathrm{l}^{-1}$ BC-G, moisturized till $70 \%$ of full water capacity. 20 cucumber plant (Cucumis sativus L., 'Grīvas') seeds were sown in each box. Seed germination was assessed on day 6 after sowing. Development of above and underground parts of seedlings was measured on day 12 and 18 after sowing using 10 plants from each box. The root system was evaluated using a calibrated rhizoscanner STD $-1600+$ (Win Rhizo 2002 C). WinRHIZO is an image analysis system specifically designed for root measurement in different forms. It performs morphology (length, area, volume), topology, architecture, and colour analyses. It consists of a computer program and an image acquisition scanner with a working area $30 \times 42 \mathrm{~cm}$.

The experiment was performed in triplicate. Data presented in the figures are expressed as mean \pm standard deviation at a 5\% level of significance. Comparisons among the treatments were assessed by the Student $t$ test and one-way analysis of variance (ANOVA).

\section{RESULTS AND DISCUSSION}

Judging by literature on the topic, the addition of $\mathrm{BC}$ to soil can lead to changes in the physico-chemical properties of soil, in particular, water-holding capacity, cation exchanging capacity, $\mathrm{pH}$ value, bulk density etc. (Barrow, 2012; Kookana et al., 2011; Lehmann and Joseph, 2009). This effect is likely to be biochar- and soil- specific, as well as dose-dependent. Sandy soils are known to be highly sensitive to the addition of $\mathrm{BC}$. Otherwise, a peat substrate, which is rich in organic matter and has a rather high buffering capacity, is expected to exhibit another relationship with the $\mathrm{pH}$ level in the presence of BC. For example, as reported by Steiner and Harttung (2014), in experiments with wood-derived biochar, biochar peat blends containing up to $80 \%$ biochar did not show increased $\mathrm{pH}$ above 7 .

In our study, the $\mathrm{pH}$ value of a peat-sand substrate amended with 2, 4 and $20 \mathrm{~g} \mathrm{~g} \mathrm{l}^{-1}$ biochar was tested. The $\mathrm{pH}$ value of a non-amended substrate measured in water, $\mathrm{KCl}$, and $\mathrm{CH}_{3} \mathrm{COONa}$ was found to be 5.6, 6.0, and 7.0, respectively. The BC-G suspended in these three media showed a $\mathrm{pH}$ value of $11.0,10.4$, and 10.9, respectively. An increase in the $\mathrm{pH}$ level of the peat-sand substrate with the increasing biochar concentration was detected (Fig.1a). Statistical analysis showed that these changes were significant. In particular, the $\mathrm{pH}\left(\mathrm{H}_{2} \mathrm{O}\right)$ of the substrate with 4 and $20 \mathrm{~g} \mathrm{l}^{-1}$, compared with the non-amended substrate, showed changes with the level of significance of $p<0.04$ and $p<0.02$, respectively. Similar results were obtained for $\mathrm{pH}$ measurements in $\mathrm{CH}_{3} \mathrm{COONa}$. Conversely, in the analysis of the substrate amended with $4 \mathrm{~g} \mathrm{l}^{-1}$ biochar in $\mathrm{KCl}$ solution, the increase in $\mathrm{pH}$ was not significant $(\mathrm{p}=0.12)$ in comparison with the non-amended substrate. In contrast, addition of $20 \mathrm{~g} \mathrm{l}^{-1}$ biochar to the peat-sand substrate resulted in a significant $(\mathrm{p}<0.04)$ increase in $\mathrm{pH}(\mathrm{KCl})$.

Addition of acid and alkali led to changes in the $\mathrm{pH}$ values, which were detected in both the non-amended and the $4 \mathrm{~g} \mathrm{l}^{-1}$ containing peat-sand substrate. The presence of $4 \mathrm{~g} \mathrm{l}^{-1} \mathrm{BC}-\mathrm{G}$ in the substrate did not influence the relationship between the addition of alkali/acid and the $\mathrm{pH}$ value (Fig. 1b). Addition of $5 \mathrm{ml} 0.1 \mathrm{~N} \mathrm{NaOH}$ to the substrate with the final volume of $13 \mathrm{ml}$ resulted in raising $\mathrm{pH}$ by up to 3 units. In turn, $5 \mathrm{ml}$ of $0.1 \mathrm{~N} \mathrm{H}_{2} \mathrm{SO}_{4}$ decreased the $\mathrm{pH}$ level
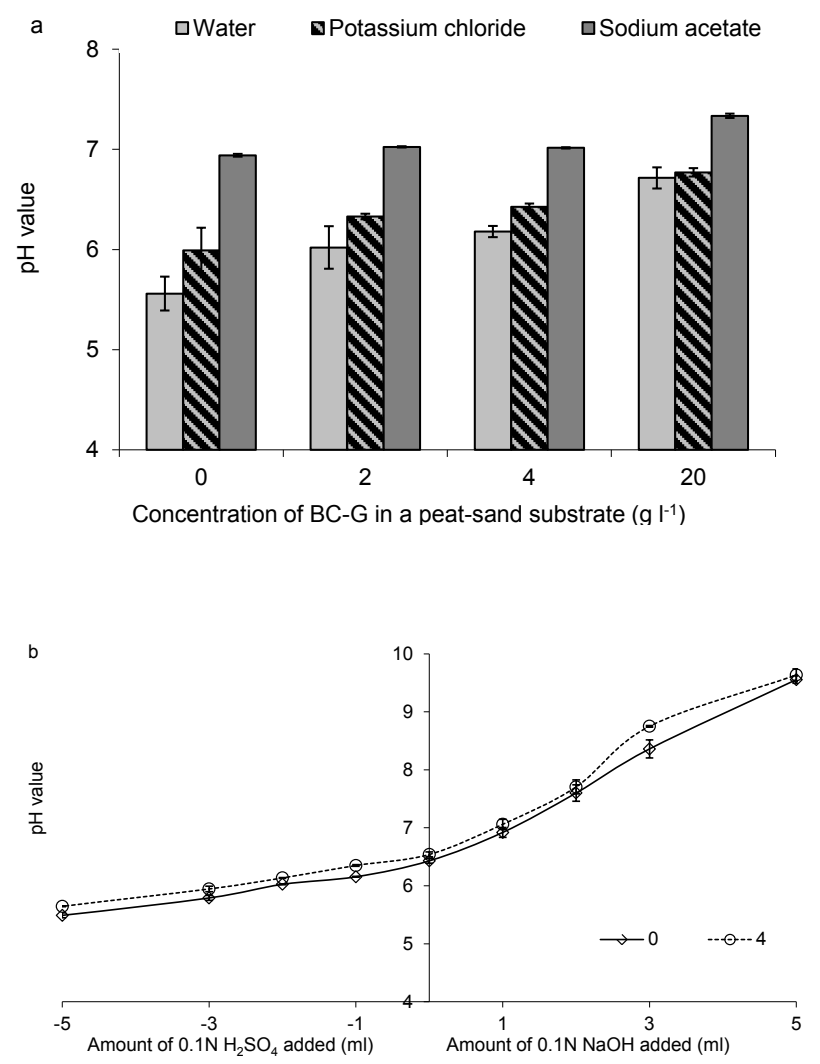

Fig. 1. $\mathrm{pH}$ values of the peat-sand substrate suspension amended with $\mathrm{BC}-\mathrm{G}$ detected in different media: $\mathrm{a}-\mathrm{pH}$ value of the peatsand substrate amended with $0,2,4$, and $20 \mathrm{~g} \mathrm{l}^{-1} \mathrm{BC}-\mathrm{G} ; 1 \mathrm{~N} \mathrm{KCl}$ and $1 \mathrm{~N} \mathrm{CH}_{3} \mathrm{COONa}$ were used; $\mathrm{b}$ - effect of acid and alkali addition on the $\mathrm{pH}$ value of the suspension of the peat-sand substrate with $4 \mathrm{~g} \mathrm{l}^{-1} \mathrm{BC}-\mathrm{G}$ (4) and without BC-G (0). 
of the substrate suspension only by 1.2 units (Fig. 1b). The data obtained show that in the case of a comparatively high content of biochar in the substrate, the application of $1 \mathrm{M}$ $\mathrm{KCl}$ solution for $\mathrm{pH}$ measurement is not desirable due to the high cation-exchange capacity of biochar, because it could reduce the result, as found in the test with pure BC-G (data not shown).

Another important characteristic for agricultural soil/ soil substrate quality is water holding capacity. In our experiments, the maximum moisture holding capacity of the peat-sand substrate amended with 2,4 , and $20 \mathrm{~g} \mathrm{l}^{-1}$ biochar varied in the range from 173 to $186 \%$. The average data for the non-amended substrate and pure BC-G were 190 and 269\%, respectively (Table 1). However, statistical analysis of these results indicated that no significant difference in WHC between the pure substrate, the BC-G amended substrate, and the pure BC-G was found. In particular, the F-test for the pure substrate and pure BC-G showed $p=0.216$. As known from literature, introduction of biochar into soil can potentially increase its WHC; however, this effect depends on physico-chemical properties of biochar, in particular, its hydrophobicity (Sohi et al., 2010). Our results showed that WHC of BC-G is slightly higher than that for the substrate ie 269 and 190\% (w/w), respectively. However, this difference is due to the considerably lower density of BC-G as compared to the substrate (Table 1).

Sohi et al. (2010) reported that the effect of biochar introduction in soil was soil-specific and did not depend on the application rate in the range of $5 \div 15 \mathrm{tha}^{-1}$. An increase in WHC induced by biochar application was more effective in sandy textured soils (Dugan et al., 2010). Johnson et al. (2012) reported that biochar mixing ratios of $10 \%(\mathrm{v} / \mathrm{v})$ and greater provided water holding capacity equivalent to peatbased potting mixes. In our experiments with the peat-sand substrate, the tested biochar did not significantly change the soil WHC in the studied BC-G application rates.

The mechanisms of the influence of biochar on soil microorganisms are studied by a wide spectrum of methodological approaches (Graber et al., 2010; Kolb et al., 2009; Steiner et al., 2008). Soil microbial respiration is one of the criteria for assessing microbial response to the presence of $\mathrm{BC}$. However, sorption properties of biochars

T a b l e 1. Changes in water absorbing capacity of the peat-sand substrate in relation to the presence of BC-G

\begin{tabular}{|c|c|c|c|c|c|}
\hline \multirow{2}{*}{ Parameter } & \multicolumn{4}{|c|}{$\mathrm{BC}-\mathrm{G}$ rate in a peat-sand substrate $\left(\mathrm{g} \mathrm{l}^{-1}\right)$} & \multirow{2}{*}{$100 \% \mathrm{BC}-\mathrm{C}$} \\
\hline & 0 & 2 & 4 & 20 & \\
\hline $\begin{array}{l}\text { Maximum moisture holding } \\
\text { capacity } \%(\mathrm{w} / \mathrm{w})\end{array}$ & 190.0 & 177.8 & 181.5 & 186.0 & 269.2 \\
\hline $\begin{array}{l}\text { Water required to saturate } \\
100 \mathrm{~cm}^{-3} \text { of } \mathrm{dw}(\mathrm{g})\end{array}$ & 111.6 & 100.8 & 101.5 & 109.6 & 80.8 \\
\hline
\end{tabular}

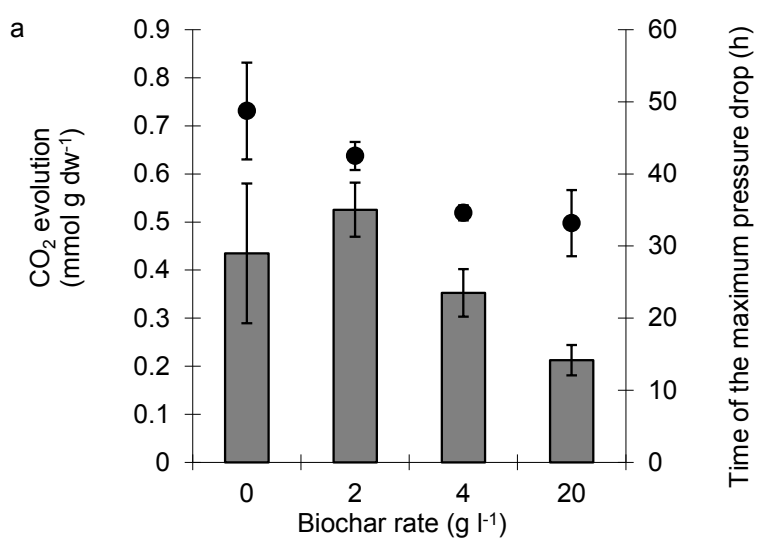

$\square$ Number of carbon dioxide moles at the maximum pressure drop (mmol)

- Time of the maximum pressure drop (h)

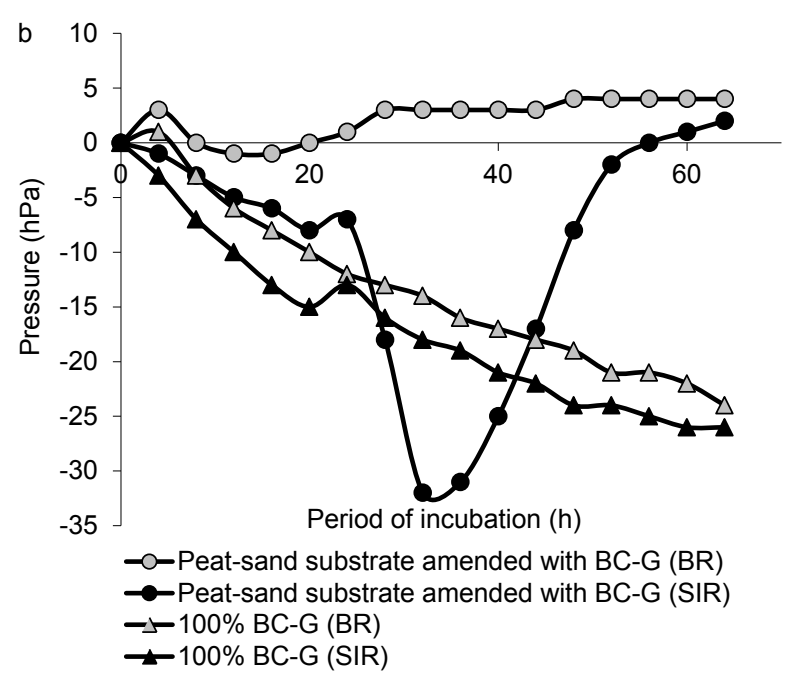

Fig. 2. Changes in $\mathrm{CO}_{2}$ evolution dynamics for the peat-sand substrate amended with different amounts of BC-G. BR - basal respiration, SIR - substrate-induced respiration ( $1 \mathrm{~g}$ glucose per $20 \mathrm{~g}$ sample): a - number of $\mathrm{CO}_{2}$ moles at the maximum pressure drop and time of the maximum pressure drop; $b$ - typical profiles of the curves corresponding to the $\mathrm{CO}_{2}$ evolution by pure $\mathrm{BC}-\mathrm{G}$ and the peatsand substrate containing $2 \mathrm{~g} \mathrm{l}^{-1} \mathrm{BC}-\mathrm{G}$. 
a

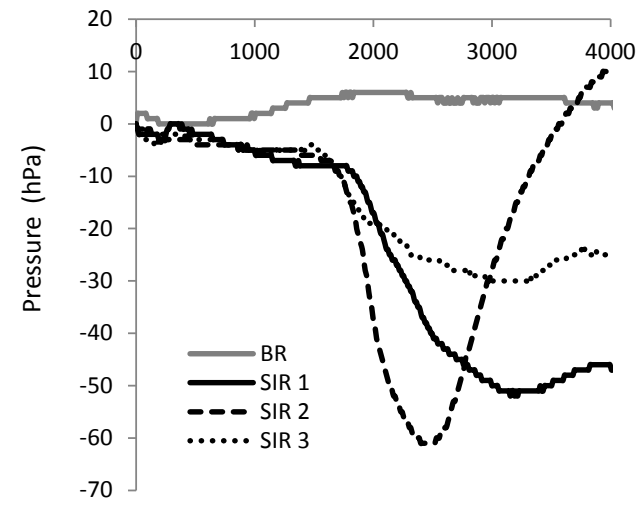

C
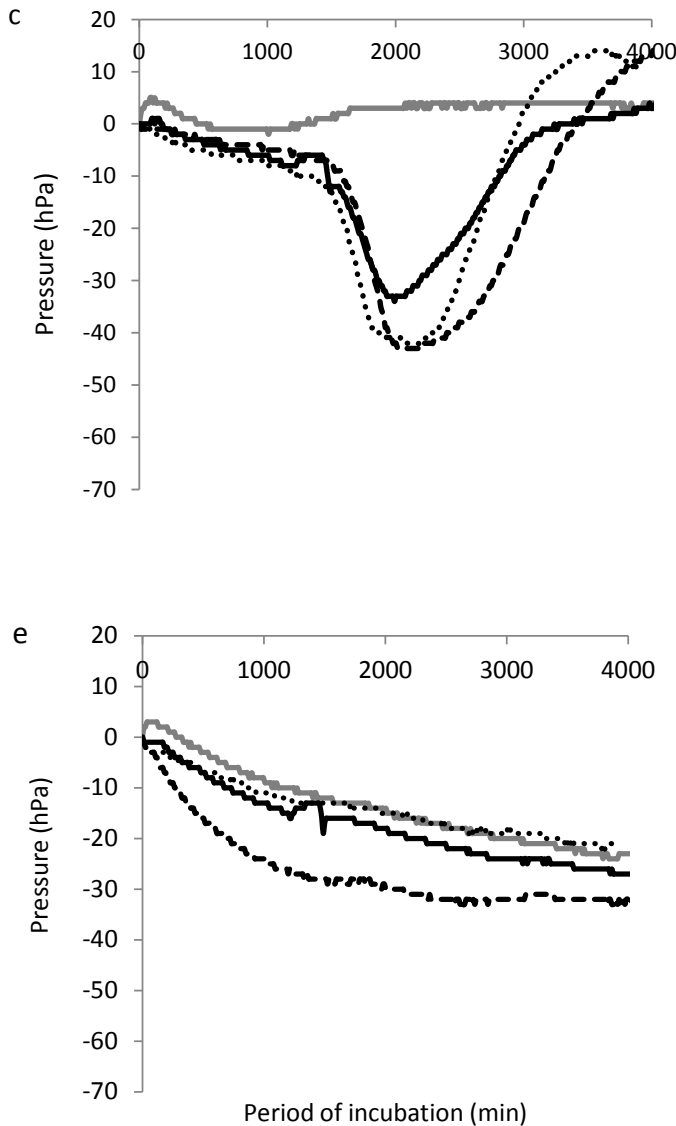

Fig. 3. Typical profiles of the pressure drop curves for the peatsand substrate and BC-G performed with the OxiTop ${ }^{\circledR}$ OC 110 respirometric system: a - peat-sand substrate without $\mathrm{BC}-\mathrm{G}$; b-2 $\mathrm{g} \mathrm{l}^{-1}$ BC-G; c- $4 \mathrm{~g} \mathrm{l}^{-1}$ BC-G; d-20 $\mathrm{g} \mathrm{l}^{-1}$ BC-G; e-BC-G without substrate. The incubation period was $67 \mathrm{~h}$ under conditions described in Section 2.4. BR - basal respiration, $20 \mathrm{~g}$ substrate amended with $18 \mathrm{ml}$ water; SIR - substrate-induced respiration, $20 \mathrm{~g}$ substrate amended with $18 \mathrm{ml}$ water and $1 \mathrm{~g}$ glucose. Testing of pure $\mathrm{BC}-\mathrm{G}$ was performed under the same conditions as for the peat-sand substrate, except the mass of BC-G taken for testing was $10 \mathrm{~g}$.

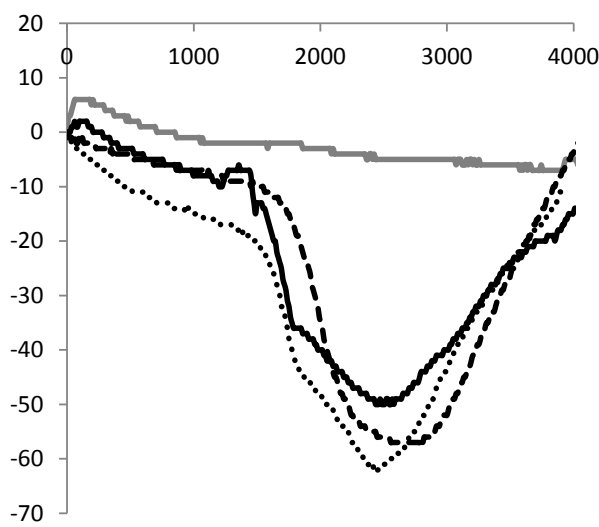

d

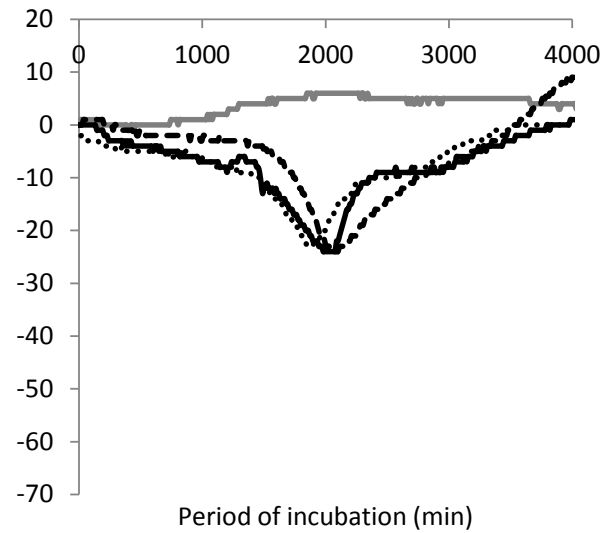

often interfere with $\mathrm{CO}_{2}$ evolution resulting from microbial respiration (Lehmann et al., 2011). Another limiting factor in interpretation of datasets obtained in respiration assays is distinguishing the oxygen used for carbon oxidation from that for nitrogen oxidation (nitrification) (Reuschenbac et al., 2003).

Comparison of the pressure drop in the bottles upon incubation of the peat-sand substrate amended with different amounts of BC-G revealed some changes in the dynamics of $\mathrm{CO}_{2}$ evolution/sorption. In particular, the increase in the $\mathrm{BC}-\mathrm{G}$ concentration resulted in a decreasing number of $\mathrm{CO}_{2}$ moles at the maximum pressure drop (Fig. 2a). At the same time, the number of $\mathrm{CO}_{2}$ moles at the maximum pressure drop in the non-amended substrate was slightly lower as compared to the set with $2 \mathrm{~g} \mathrm{l}^{-1} \mathrm{BC}-\mathrm{G}$. The time to the maximum pressure drop ranged from $48 \mathrm{~h}$ (peatsand substrate) to $33 \mathrm{~h}$ (substrate containing $20 \mathrm{~g} \mathrm{l}^{-1} \mathrm{BC}-\mathrm{G}$ ) and had a tendency to decrease with increasing BC-G concentrations in the substrate (Fig. 2a). Since the amount of $\mathrm{CO}_{2}$ evolved daily from soil hectare is rather high (up to 50 $\mathrm{kg}$ for sandy soil and 7-12 time higher for organic matterrich soil), the decrease in the amount of evolved $\mathrm{CO}_{2}$ up to 1.2 and 2.0 times, respectively, for the BC-G rate of 4 and $20 \mathrm{~g} \mathrm{l}^{-1}$ in comparison with the non-amended soil (Fig. 2a) 
could be essential. Retention of some additional $\mathrm{CO}_{2}$ quantity in the substrate may positively influence on the biodynamics of plant development. This was confirmed by the vegetation tests described below.

Typical profiles of the pressure drop curves during incubation of the peat-sand substrate amended with different concentrations of BC-G are presented in Fig. 3. The curve profiles differed in the amplitude of pressure drop in relation to the rate of $\mathrm{BC}-\mathrm{G}$ in the substrate, while the pure BC-G without substrate demonstrated a completely different curve profile, which indicates $\mathrm{CO}_{2}$ sorption (Fig. 3).

The sorption ability of BC-G is demonstrated in Fig.2. Incubation of BC-G caused a continuous decrease in pressure in the bottle regardless of the presence of glucose (Fig. 2b). Additional testing revealed the BC-G concentrationdependent character of the pressure drop under the studied conditions (results not shown). Otherwise, addition of glucose (substrate-induced respiration) to the peat-sand substrate amended with $2 \mathrm{~g} \mathrm{l}^{-1}$ biochar resulted in a pressure drop, which had a typical profile for the soil containing microorganisms.

The number of culturable bacteria and fungi was determined in all the sets with the substrate and BC-G tested in these experiments. No considerable changes were found among the samples. The number of bacteria and fungi in all the tested samples was on average $2.03 \times 10^{6} \mathrm{CFU} \mathrm{g} \mathrm{dw}^{-1}$ and $1.06 \times 10^{4} \mathrm{CFU} \mathrm{g} \mathrm{dw}^{-1}$, respectively.

The changes occurring during cucumber growth were evaluated using such criteria as seed germination and root development. After the first 6 days of the experiment, seed germination in the sets with $0,2,4 \mathrm{~g} \mathrm{l}^{-1}$ biochar was found to be 100,97 , and $97 \%$, respectively. Dry weight of the plant aboveground part and roots after 12 days in the presence of $2 \mathrm{~g} \mathrm{l}^{-1}$ biochar was by 29 and $16 \%$ higher than in the control, respectively. Root volume of these plants was by $34 \%$ higher than in the control. In turn, after 18 days, the highest increase in the dry weight of the plant aboveground part was detected in the presence of $4 \mathrm{~g} \mathrm{BC}-\mathrm{G}$ ie by $36 \%$ as compared to control. Regarding the development of the root system of cucumber seedlings, considerable changes in the root structure of plants grown in the presence of BC-G were observed. In particular, a BC-G rate-dependent increase in the number of root tips was detected. At the same time, the average root diameter was decreased. Besides, addition of BC-G to the growth substrate resulted in an increase in the root volume, regardless of the biochar rate applied (Table 2, Fig. 4).

The positive impacts of low doses (1-5\% by weight) biochar on the growth of plants were reported by Graber $e t$ al. (2010). Growth of pepper and tomato was stimulated by wood-derived biochar in a coconut fiber:tuff growing mix, but the changes observed were plant species-specific. The mechanisms of this effect were explained by the shift in the structure of soil microbial community towards beneficial rhizobacteria or fungi, as well as by the positive effect of low doses of biochar chemicals (hormesis) (Graber et al., 2010). However, even with the same application rate of biochar, a large variation in the effect size occurs, due to different biochar feedstocks used, different crops assessed, and differences in the soil type to which the biochar was added (Verheijen et al., 2009).

T a b l e 2. Effect of different rates of BC-G added to the peat-sand substrate on the development of seedlings of Cucumis sativus L. (Grīvas") on day 12 and 18 after sowing

\begin{tabular}{|c|c|c|c|c|c|c|}
\hline $\begin{array}{l}\text { Rate of BC-G } \\
\qquad\left(\mathrm{g} \mathrm{l}^{-1}\right)\end{array}$ & $\begin{array}{l}\text { Dry weight } \\
\text { of plant } \\
\text { aboveground } \\
\text { part (mg) }\end{array}$ & $\begin{array}{l}\text { Dry weight } \\
\text { of plant roots } \\
\text { (mg) }\end{array}$ & $\begin{array}{l}\text { Root volume } \\
\qquad\left(\mathrm{cm}^{-3}\right)\end{array}$ & $\begin{array}{l}\text { Total root length } \\
\quad(\mathrm{cm})\end{array}$ & $\begin{array}{l}\text { Average root } \\
\text { diameter } \\
(\mathrm{mm})\end{array}$ & $\begin{array}{l}\text { Number } \\
\text { of root tips } \\
\text { (pcs) }\end{array}$ \\
\hline \multicolumn{7}{|c|}{12 days after sowing } \\
\hline 0 & $45.1 \pm 2.3$ & $6.3 \pm 0.3$ & $0.056 \pm 0.003$ & $63.10 \pm 3.16$ & $0.34 \pm 0.02$ & $356 \pm 18$ \\
\hline 2 & $58.0 \pm 2.9$ & $7.3 \pm 0.4$ & $0.075 \pm 0.004$ & $80.55 \pm 4.03$ & $0.35 \pm 0.02$ & $523 \pm 26$ \\
\hline 4 & $52.2 \pm 2.5$ & $7.6 \pm 0.4$ & $0.073 \pm 0.004$ & $81.73 \pm 4.09$ & $0.34 \pm 0.02$ & $652 \pm 33$ \\
\hline \multicolumn{7}{|c|}{18 days after sowing } \\
\hline 0 & $100.2 \pm 5.0$ & $6.4 \pm 0.3$ & $0.065 \pm 0.003$ & $95.69 \pm 4.78$ & $0.30 \pm 0.02$ & $500 \pm 25$ \\
\hline 2 & $110.1 \pm 5.5$ & $7.5 \pm 0.4$ & $0.077 \pm 0.004$ & $99.66 \pm 4.98$ & $0.31 \pm 0.02$ & $585 \pm 29$ \\
\hline 4 & $136.0 \pm 6.8$ & $7.6 \pm 0.4$ & $0.078 \pm 0.004$ & $100.48 \pm 5.02$ & $0.31 \pm 0.02$ & $670 \pm 34$ \\
\hline
\end{tabular}

Confidence intervals are calculated at a confidence level of $95 \%$. 


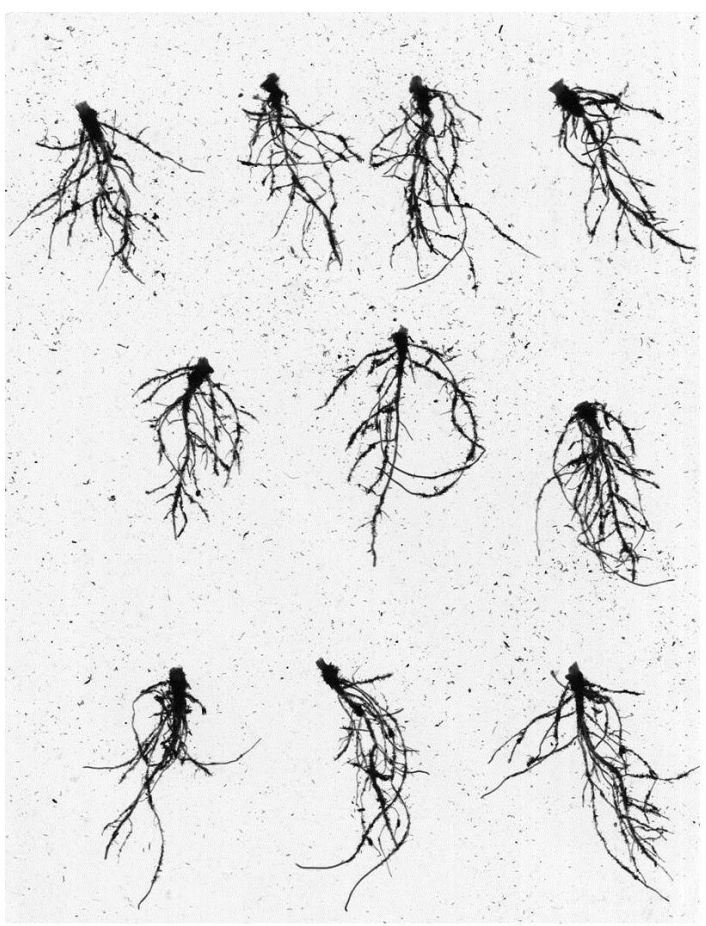

$4 \mathrm{~g} \mathrm{l}^{-1} \mathrm{BC}-\mathrm{G}$

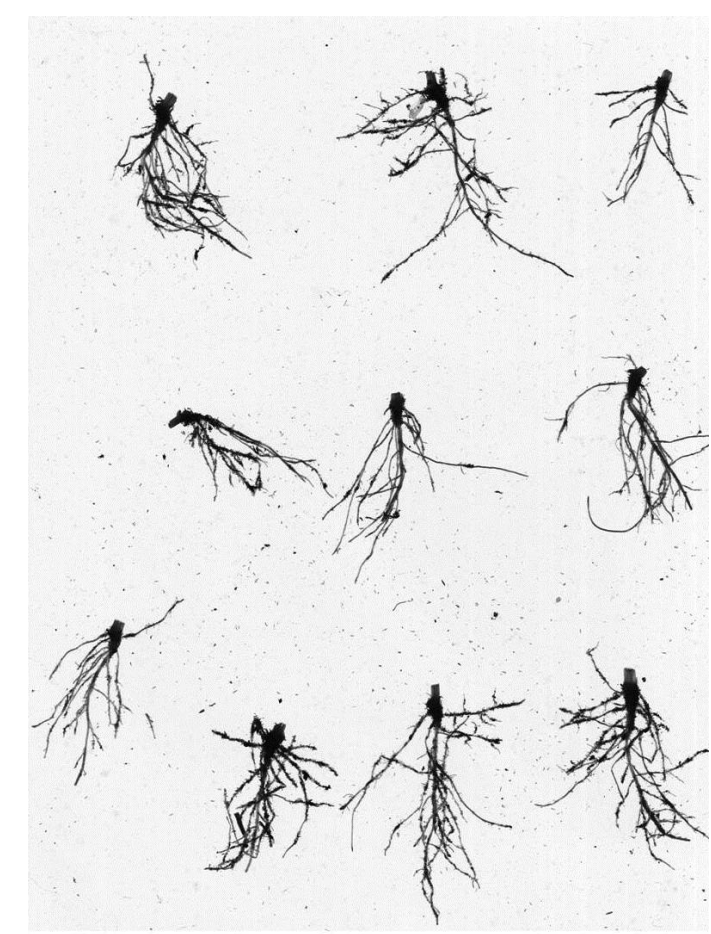

Control (without BC-G)

Fig. 4. Roots of Cucumis sativus L. ('Grīvas') grown during 18 days in the peat-sand substrate amended with $4 \mathrm{~g} \mathrm{l^{-1 }} \mathrm{BC}-\mathrm{G}$ and without BC-G. Images were made using an image analysis system Win Rhizo 2002 C.

\section{CONCLUSIONS}

1. Biochar obtained by gasification of hardwood fuel granules and used as amendment for a peat-sand (3:1) substrate with the biochar rate of 2,4 , and $20 \mathrm{~g} \mathrm{l}^{-1}$ significantly $(\mathrm{p}<0.05)$ increased the $\mathrm{pH}$ level of the substrate. In particular, the $\mathrm{pH}\left(\mathrm{H}_{2} \mathrm{O}\right)$ of the substrate with $4 \mathrm{~g} \mathrm{l}^{-1}$ and $20 \mathrm{~g} \mathrm{l}^{-1}$ BC-G was increased from 5.6 to 6.2 and 6.7 , respectively. Water holding capacity of the substrate was not considerably changed when amended with the tested concentrations of BC-G. Based on the results with pure BC-G, the use of $1 \mathrm{M} \mathrm{KCl}$ for $\mathrm{pH}$ measurement of the substrate with a high $\mathrm{BC}-\mathrm{G}$ rate is not recommended to due to its cation-exchange ability, which can be the cause of mistakes.

2. Introduction of BC-G into the substrate led to decreasing $\mathrm{CO}_{2}$ evolved at the maximum pressure drop, which was detected by the respirometry device. Retention of some additional $\mathrm{CO}_{2}$ quantity in the substrate may positively influence the biodynamics of plant development.

3. The 18-day vegetation test with cucumbers has shown a stimulation effect of $2 \mathrm{~g} \mathrm{l}^{-1}$ and $4 \mathrm{~g} \mathrm{l}^{-1} \mathrm{BC}-\mathrm{G}$ in the peatsand substrate on the biometric indices of the aboveground part and roots. Considerable changes in the root structure of plants grown in the presence of BC-G were observed.
In particular, an increase in the number of root tips and a decrease in the average root diameter with an increased root volume were shown.

4. Further investigations are required for optimization of BC-G dosages with emphasis on the specific BC combination, soil type, plant species, climatic condition, etc.

\section{REFERENCES}

Angst T.E., Patterson C.J., Reay D.S., Anderson P., Peshkur T.A., and Sohi S.P., 2013. Biochar diminishes nitrous oxide and nitrate leaching from diverse nutrient sources. J. Environ. Quality, 43(2), 672-682.

Barrow C.J., 2012. Biochar: Potential for countering land degradation and for improving agriculture. Appl. Geogr., 34, 21-28.

Cayuela M.L., Sánchez-Monedero M.A., Roig A., Hanley K., Enders A., and Lehmann J., 2013. Biochar and denitrification in soils: When, how much and why does biochar reduce $\mathrm{N}_{2} \mathrm{O}$ emissions? Scientific Reports, 3, 1732, doi:10.1038/srep01732.

Černohlávková J., Jarkovský J., and Hofman J., 2009. Effects of fungicides mancozeb and dinocap on carbon and nitrogen mineralization in soils. Ecotoxicology Environ. Safety, 72, 80-85. 
Chintala R., Mollinedo J., Schumacher T.E., Malo D.D., and Julson J.L., 2013. Effect of biochar on chemical properties of acidic soil. Archives Agronomy Soil Sci., DOI: 10.1080/03650340.2013.789870.

Cleary J., Roulet N.T., and Moore T.R., 2005. Greenhouse gas emissions from Canadian peat extraction 1990-2000: a lifecycle-analysis. Ambio, 34, 456-461, doi:10.1579/00447447-34.6.456.

Dugan E., Verhoef A., Robinson S., and Sohi S., 2010. Bio-char from sawdust, maize stover and charcoal: impact on water holding capacities (WHC) of three soils from Ghana, in: Proc. 19th World Congress of Soil Science, Soil Solutions for a Changing World, August 1-6, Brisbane, Australia.

Dumroese R.K., Heiskanen J., Englund K., and Tervahauta A., 2011. Pelleted biochar: Chemical and physical properties show potential use as a substrate in container nurseries. Biomass Bioenergy, 35(5), 2018-2027.

Graber E.R., Harel Y.M., Kolton M., Cytryn E., Silber A., David D.R., Tsechansky L., Borenshtein M., and Elad Y., 2010. Biochar impact on development and productivity of pepper and tomato grown in fertigated soilless media. Plant Soil, 337(1), 481-496.

Hass A., Gonzalez J.M., Lima I. M., Godwin H.W., Halvorson J.J., and Boyer D.G., 2012. Chicken manure biochar as liming and nutrient source for acid appalachian soil. J. Environ. Quality, 41(4), 1096-1106.

Johnson M.S., Hilbert I., and Jollymore A.J., 2012. Biochar as a substitute for peat in greenhouse growing media: soil water characteristics and carbon leaching dynamics. Book of Abstracts, AGU Fall meeting, December 3-7, San Francisco, USA.

Kolb S.E., Fermanich K.J., and Dornbush M.E., 2009. Effect of charcoal quantity on microbial biomass and activity in temperate soils. Soil Sci. Soc. America J., 73(4), 1173-1181.

Kookana R.S., Sarmah A.K., Van Zwieten L., Krull E., and Singh B., 2011. Chapter three - Biochar application to soil: agronomic and environmental benefits and unintended consequences. Advances Agronomy, 112, 103-143.

Lehmann J., Gaunt J., and Rondon M., 2006. Bio-char sequestration in terrestrial ecosystems - A review. Mitigation and Adaptation Strategies Global Change, 11(2), 403-427.

Lehmann J. and Joseph S., 2009. Biochar for Environmental Management: Science and Technology. Earthscan, London, UK.

Lehmann J., Rillig M.C., Thies J., Masiello C.A., Hockaday W.C., and Crowley D., 2011. Biochar effects on soil biota. A review. Soil Biol. Biochem., 43(9), 1812-1836.

Liu X., Zhang A., Ji C., Joseph S., Bian R., Li L., Pan G., and Paz-Ferreiro J., 2013. Biochar's effect on crop productivity and the dependence on experimental conditions-a meta-analysis of literature data. Plant Soil, DOI:10.1007/ s11104-013-1806-X.
Michel J.-C., 2010. The physical properties of peat: a key factor for modern growing media. Mires and Peat, http://www. mires-and-peat.net

Novak J.M., Lima I., Xing B., Gaskin J.W., Steiner C., Das K.C., Ahmedna M., Rehrah D., Watts D.W., Busscher W.J., and Schomberg H.H., 2009. Characterization of designer biochar produced at different temperatures and their effects on a loamy sand. Annals Environ. Sci., 3, 195-206.

Olszewski J.M., Lozano N., Haines C., Rice C.P., Ramirez M., and Torrents A., 2013. The effect of liming on antibacterial and hormone levels in wastewater biosolids. J. Environ. Sci. Health - Part A Toxic/Hazardous Substances Environ. Eng., 48(8), 862-870.

Reuschenbac P., Pagga U., and Strotmann U., 2003. A critical comparison of respirometric biodegradation tests based on OECD 301 and related test methods. Water Res., 37, 1571-1582.

Sadaka S.S., Richard T.L., Loecke T.D., and Liebman M., 2006. Determination of compost respiration rates using pressure sensors. Compost Sci. Utilization, 14(2), 124-131.

Sohi S.P., Krull E., Lopez-Capel E., and Bol R., 2010. A review of biochar and its use and function in soil. Advances Agronomy, 105, 47-82.

Stavi I., 2013. Biochar use in forestry and tree-based agro-ecosystems for increasing climate change mitigation and adaptation. Int. J. Sustainable Develop. World Ecology, 20(2), 166-181.

Steiner C. and Harttung T., 2014. Biochar as growing media additive and peat substitute. Solid Earth Discussions, 6, 1023-1035.

Steiner C., Glaser B., Teixeira W.G., Lehmann J., Blum W.E.H., and Zech W., 2008. Nitrogen retention and plant uptake on a highly weathered central Amazonian Ferralsol amended with compost and charcoal. J. Plant Nutrition Soil Sci., 171(6), 893-899.

Telysheva G., Dobele G., Lebedeva G., Volpert A., Muter O., and Strikauska S., 2013. Biochar of different origin as an amendment for planted soil. Book of Abstracts, 2nd Nordic Biochar Seminar, February 14-15, Helsinki, Finland.

Tian Y., Sun X., Li S., Wang H., Wang L., Cao J., and Zhang L., 2012. Biochar made from green waste as peat substitute in growth media for Calathea rotundifola cv. Fasciata. Scientia Horticulturae, 143, 15-18.

Verheijen F.G.A., Jeffery S., Bastos A.C., van der Velde M., and Diafas I., 2009. Biochar Application to Soils - A Critical Scientific Review of Effects on Soil Properties, Processes and Functions. EUR 24099 EN, Office for the Official Publications of the European Communities, Luxembourg. 